\title{
Effect of Treatment with Octreotide on the Morphology of Growth Hormone-secreting Pituitary Adenomas: Study of 24 Cases
}

\author{
Albert Beckers, M.D., Ph.D., Kalman Kovacs, M.D., Ph.D., \\ Eva Horvath, Ph.D., Roger Abs, M.D., \\ Michel Reznik, M.D., Ph.D., and Achille Stevenaert, M.D., Ph.D.
}

\begin{abstract}
Twenty-four acromegalic patients were treated with octreotide subcutaneously for periods of 3 to 6 weeks (group I, 12 cases) or 6 months (group II, 12 cases) before transsphenoidal surgery. Radiological studies performed in 19 patients before and at the end of this treatment period revealed no changes in 8 cases. In 8 other cases, a slight reduction in turnor size was observed, and in 3 cases an important shrinkage was documented. At surgery, the adenomatous tissue appeared softer than in nonpretreated patients, facilitating the operation. Pathological examination revealed widening of perivascular spaces with accumulation of fibrous tissue and more crinophagy than in nonpretreated patients but failed to reveal morphologically pronounced cell involution as observed in prolactin-producing adenomas treated with dopamine agonists. No significant difference in frequency or extent of cellular changes was noted between the two groups. These morphological findings seem to be more consistent with a functional inhibition of growth hormone release than with cellular alterations induced by octreotide. Endocr Pathol 2:123-131, 1991.
\end{abstract}

Departments of Endocrinology (AB), Pathology (MR), and Neurosurgery (AS), CHU, University of Liège, Belgium; Department of Pathology, St. Michael's Hospital, University of Toronto, Canada (KK, EH); and Department of Endocrinology, University of Antwerp, Belgium (RA).

Address correspondence to Dr. Beckers, University of Liège, CHU-B35, Department of Endocrinology, B-4000 Sart-Tilman Liège, Belgium.
Although natural somatostatin strongly inhibits growth hormone (GH) secretion, it could not be used successfully in the treatment of acromegaly due to its short half-life and because of the rebound secretion of GH after cessation of the infusion [6]. Recently, a new somatostatin analog, octreotide (Sandostatin, Sandoz Ltd., Basel, Switzerland), with a marked and prolonged inhibitory effect on GH secretion, became available for clinical use $[5,13,15]$. In this article, we report data recorded from 24 acromegalic patients treated with octreotide before transsphenoidal surgery. Radiological evolution and appearance of the adenoma at surgery are reviewed. Special attention is given to possible morphological changes induced by octreotide.

\section{Materials and Methods}

This series includes 24 acromegalic patients (13 men and 11 women, aged 28-63 years). Diagnosis of acromegaly was made clinically and was confirmed biochemically by elevated serum GH and plasma insulinlike growth factor I (IGF-I) concentrations and radiologically by demonstration of a pituitary tumor by computed tomography (CT) scanning or magnetic resonance imaging (MRI). Pertinent clinical data are reported in Table 1.

Octreotide was given at a constant dose of $3 \times 100 \mu \mathrm{g} /$ day subcutaneously for 3 to 6 weeks before transsphenoidal surgery in 12 patients (group I, cases 1-12). Twelve patients (group II, cases 13-24) were treated for 6 months before surgery. In this group, the 
Table 1. Clinical, radiological, and surgical data (groups I and II)

\begin{tabular}{|c|c|c|c|c|c|c|}
\hline $\begin{array}{l}\text { Case } \\
\text { No. } \\
\end{array}$ & $\begin{array}{l}\text { Age }(y r) / \\
\text { Sex }\end{array}$ & $\begin{array}{l}\text { Previous } \\
\text { Treatment } \\
\text { (Duration or } \\
\text { Year of Treatment) }\end{array}$ & Grading & $\begin{array}{l}\text { Octreotide-Induced } \\
\text { Size Reduction }\end{array}$ & $\begin{array}{l}\text { Tumor } \\
\text { Diameter }(\mathrm{mm}) \\
\text { at Surgery }\end{array}$ & $\begin{array}{l}\text { Tissue } \\
\text { Aspect } \\
\text { at Surgery }\end{array}$ \\
\hline 1 & $63 / \mathrm{M}$ & $\mathrm{B}(2 \mathrm{yr})$ & I & None & 9 & Soft \\
\hline 2 & $63 / \mathrm{F}$ & 0 & I & Slight & 10 & Firm \\
\hline 3 & $56 / F$ & 0 & I & None & 10 & Soft \\
\hline 4 & $41 / F$ & 0 & I & Slight & 10 & Firm \\
\hline 5 & $56 / F$ & $\mathrm{~B}(6 \mathrm{mo})$ & II & None & 13 & Soft \\
\hline 6 & $59 / F$ & 0 & II & None & 13 & Soft \\
\hline 7 & $35 / F$ & 0 & II & None & 15 & Soft \\
\hline 8 & $43 / \mathrm{M}$ & $\mathrm{B}(2 \mathrm{mo})$ & III & Slight & 20 & $\begin{array}{l}\text { Soft, necrotic, } \\
\text { hemorrhagic }\end{array}$ \\
\hline 9 & $59 / \mathrm{M}$ & $\begin{array}{l}\mathrm{R}(1976) \\
\mathrm{B}(10 \mathrm{yr})\end{array}$ & III & Slight & 25 & Soft, hemorrhagic \\
\hline 10 & $56 / \mathrm{M}$ & 0 & III & Pronounced & 25 & Soft, hemorrhagic \\
\hline 11 & $31 / M$ & 0 & III-A & Slight & 25 & $\begin{array}{l}\text { Soft, necrotic, } \\
\text { hemorrhagic }\end{array}$ \\
\hline 12 & $39 / \mathrm{M}$ & $\begin{array}{l}S(1977) \\
B(8 \mathrm{yr})\end{array}$ & IV $-\mathrm{A}$ & None & 50 & Fibrotic \\
\hline 13 & $54 / F$ & 0 & 1 & Slight & 8 & Soft \\
\hline 14 & $37 / M$ & 0 & 1 & None & 10 & Liquid \\
\hline 15 & $58 / \mathrm{M}$ & 0 & 1 & Pronounced & 10 & Soft \\
\hline 16 & $43 / \mathrm{M}$ & 0 & II & Pronounced & 12 & Soft \\
\hline 17 & $28 / \mathrm{M}$ & 0 & II & Slight & 14 & Soft \\
\hline 18 & $34 / \mathrm{M}$ & 0 & II & NC & 14 & Soft \\
\hline 19 & $35 / M$ & 0 & II & NC & 15 & Soft with fibrous septa \\
\hline 20 & $51 / F$ & 0 & II & Slight & 16 & Soft \\
\hline 21 & $59 / F$ & 0 & III & $\mathrm{NC}$ & 14 & Soft \\
\hline 22 & $29 / \mathrm{F}$ & 0 & III & None & 16 & Soft \\
\hline 23 & $47 / \mathrm{F}$ & 0 & III & NC & 16 & Soft with hard peel \\
\hline 24 & $35 / \mathrm{M}$ & 0 & III-A & NC & 23 & Firm \\
\hline
\end{tabular}

dose of octreotide was augmented to $3 \times 500$ $\mu \mathrm{g} /$ day when a decrease in therapeutic effect was experienced, as expressed by a loss of inhibition of GH and IGF-I secretion. The last injection was given in each case 4 hours before surgery.

The study was approved by the local ethical committee. The purpose of the study was explained to the patients, who gave their oral consent.

\section{Radiological Study}

The pituitary region was evaluated by $\mathrm{CT}$ scanning using a Siemens Somatom $2 \mathrm{~N}$ or by
MRI using a Siemens Magnetom before octreotide treatment and after 3 weeks in group I and after 6 months in group II. Grading and suprasellar extension were assessed as previously described $[11,22]$. The largest diameter of the cavity was also measured after adenomectomy.

\section{Morphological Study}

For light microscopy, small pieces of tumor tissue were fixed in Bouin's solution, dehydrated in a series of graded ethanols, and embedded in paraffin. Sections were stained 
Table 2. Pathological data (group I)

\begin{tabular}{|c|c|}
\hline Case No. & $\begin{array}{l}\text { Light Microscopical } \\
\text { Findings }\end{array}$ \\
\hline 1 & $\begin{array}{l}\text { Acidophilic adenoma } \\
\text { Immunopositivity: GH, PRL } \\
\text { (few cells) } \\
\text { Fibrosis: no }\end{array}$ \\
\hline 2 & $\begin{array}{l}\text { Acidophilic adenoma } \\
\text { Immunopositivity: GH } \\
\text { (strong), PRL (10\%), LH } \\
\text { (occasional cells) } \\
\text { Fibrosis: no }\end{array}$ \\
\hline 3 & $\begin{array}{l}\text { Diffuse adenoma } \\
\text { Immunopositivity: } \mathrm{GH} \\
\text { Fibrosis: no }\end{array}$ \\
\hline 4 & $\begin{array}{l}\text { Strongly acidophilic ade- } \\
\text { noma } \\
\text { Immunopositivity: } \mathrm{GH} \\
\text { Fibrosis: no }\end{array}$ \\
\hline 5 & $\begin{array}{l}\text { Diffuse adenoma } \\
\text { Immunopositivity: GH, PRL } \\
\text { (few cells) } \\
\text { Fibrosis: no }\end{array}$ \\
\hline 6 & $\begin{array}{l}\text { Diffuse adenoma } \\
\text { Immunopositivity: GH } \\
\text { Fibrosis: minimal, focal }\end{array}$ \\
\hline
\end{tabular}

Immunonegativity: $\mathrm{GH}$ in choristoma

Fibrosis: focal, partly perivascular

Chromophobic-acidophilic

\section{Electron Microscopical Findings}

Densely granulated mammosomatotroph

Lysosomal accumulation: mild

Perivascular fibrosis: mild

Endocrine amyloid

Densely granulated GH cell adenoma

Lysosomal accumulation: moderate

Perivascular fibrosis: mild to moderate

Very densely granulated GH cell adenoma, consisting of small cells

Lysosomal accumulation: no

Widening of perivascular space

Very densely granulated GH cell adenoma

Lysosomal accumulation: no

Widening of perivascular space

Densely granulated GH cell adenoma

Widening of perivascular space

Densely granulated GH cell adenoma

Lysosomal accumulation: mild

Perivascular fibrosis: mild to moderate

Sparsely granulated GH cell adenoma

Lysosomal accumulation: mild

Endocrine amyloid

Sparsely granulated GH cell adenoma

Lysosomal accumulation: no

Perivascular fibrosis: mild to moderate adenoma, with focal hemorrhage

Immunopositivity: GH, PRL (few cells)

Fibrosis: focal, slightly perivascular with hematoxylin-eosin to establish histological diagnosis.

For immunocytochemistry, the PAP technique was used [20]. Paraffin sections of 4- to $6-\mu \mathrm{m}$ thickness were immunostained for $\mathrm{GH}$, prolactin (PRL), luteinizing hormone (LH), follicle-stimulating hormone (FSH), thyroid-stimulating hormone (TSH), and adrenocorticotropic hormone (ACTH). Dilution of primary antibodies varied from 100 to 640; duration of exposure to the primary antibody was 30 minutes. Negative controls were performed by incubating the sections with the same dilutions of normal rabbit serum as were employed for the corresponding specific antiserum.

For electron microscopy, small parts of tumor tissue were fixed in $4 \%$ glutaraldehyde, osmicated, dehydrated, and embedded in Epon. Ultrathin sections were stained with uranyl acetate and lead citrate and investigated with a Philips 410-LS electron microscope.

\section{Results}

In group I, octreotide treatment resulted in clinical improvement and a marked reduction of serum GH and plasma IGF-I concentrations, except in 1 case (case 12). In group II, the initial inhibition of GH and IGF-I secretion with $3 \times 100 \mu \mathrm{g}$ octreotide was only retained in 3 cases $(13,15,16)$, whereas in 4 cases $(18,20,22,23)$ the same therapeutic effect was retrieved by increasing the dose. In 5 cases $(14,17,19,21,24)$, the increase of the octreotide dose to $3 \times 500 \mu \mathrm{g}$ could not correct the progressive hormonal deterioration but still maintained GH and IGF-I levels below pretreatment values.

\section{Radiological Data}

In group $I$, no change in tumor size was observed in 6 cases after 3 weeks of treatment (see Table 1). In 5 cases, a slight reduction could be seen, and in 1 case marked shrinkage was observed. In group II, no changes were observed after 6 months of treatment in 2 cases, whereas 3 tumors showed a slight regression and 2 others were markedly smaller.

\section{Surgical Data}

In group I, the adenomatous tissue appeared soft or hemorrhagic in 9 cases (see Table 1). 
Table 2. (continued)

\begin{tabular}{|c|c|c|}
\hline 10 & $\begin{array}{l}\text { Acidophilic adenoma, with } \\
\text { nuclear pleomorphism } \\
\text { and cyst formation } \\
\text { Immunopositivity: GH } \\
\text { (strong) } \\
\text { Fibrosis: no }\end{array}$ & $\begin{array}{l}\text { Densely granulated } \mathrm{GH} \text { cell } \\
\text { adenoma } \\
\text { Lysosomal accumulation: } \\
\text { mild } \\
\text { Perivascular fibrosis: moder } \\
\text { ate }\end{array}$ \\
\hline 11 & $\begin{array}{l}\text { Adenoma } \\
\text { Immunopositivity: } \mathrm{GH} \text { (fo- } \\
\text { cal) } \\
\text { Fibrosis: focal, perivascular }\end{array}$ & $\begin{array}{l}\text { Sparsely granulated } \mathrm{GH} \text { cell } \\
\text { adenoma } \\
\text { Lysosomal accumulation: } \\
\text { mild }\end{array}$ \\
\hline 12 & $\begin{array}{l}\text { Fibrous tissue trapping a few } \\
\text { small adenoma cells } \\
\text { Immunopositivity: GH (fo- } \\
\text { cal) } \\
\text { Fibrosis: massive }\end{array}$ & $\begin{array}{l}\text { Densely and sparsely granu- } \\
\text { lated adenoma cells } \\
\text { Lysosomal accumulation: no } \\
\text { Endocrine amyloid }\end{array}$ \\
\hline
\end{tabular}

$\mathrm{GH}=$ growth hormone; $\mathrm{PRL}=$ prolactin $; \mathrm{LH}=$ luteinizing hormone .

In 2 cases it was firm and in 1 case fibrotic. In the latter case (12) surgical excision could not be achieved completely. In group II, the adenoma had a soft consistency in 10 cases, was liquid in 1 case, and was firm in another case.

\section{Morphological Data}

The data on cases 9 and 12 should be interpreted with care, since these patients formerly underwent pituitary radiotherapy or surgery, which could modify the morphological features of the adenoma. Five patients received bromocriptine, but it is improbable that the morphological changes were induced by this treatment, since it was stopped at least 2 months prior to the octreotide administration.

By light microscopy on hematoxylineosin-stained slides, the tumors of group I were found to be partly acidophilic and partly chromophobic adenomas, exhibiting a diffuse pattern with some variation in cellularity, slight to moderate cellular and nuclear pleomorphism, and occasional mitotic figures Table 2). With the exception of 1 case (9) in which acute hemorrhagic infarction was evident, the adenoma cells showed neither necrosis nor damage; the architecture was preserved. The capillaries showed no abnormalities; no capillary occlusion, thrombosis, or endothelial cell injury was identified. In 5 cases, minimal or slight perivascular fibrosis was noted with widening of perivascular spaces, and in 1 case (12) the fibrosis was massive. No inflammatory infiltration was evident. In 1 case (8), the adenoma cells were interspersed with nerve fibers and large cells possessing long cytoplasmic processes and a granular cytoplasm resembling nerve cells. Neural tissue was revealed in one area adjacent to the adenoma. This lesion associated with the somatotroph adenoma was regarded as representing an adenohypophyseal neuronal choristoma similar to those described elsewhere $[1,18]$. No striking differences were found in group II (Table 3). One adenoma showed signs of necrosis (case 22). Five adenomas showed mild, mainly perivascular fibrosis.

By immunocytochemistry, the adenoma cells showed varying degrees of positivity for GH. Immunoreactivity varied from case to case and even from area to area within the same tumor. The number of adenoma cells showing GH immunoreactivity was not counted. Based on nonquantitative evaluation, adenoma cells with GH immunostaining were regarded as being between 10 and $90 \%$ of the total population in the various tumors. In 5 tumors from group I and 1 tumor from group II, scattered cells (less than $10 \%$ of the cell population) yielded PRL immunoreactivity. The PRL immunoreactivity was more pronounced in one adenoma of group II. Immunostainings for LH, FSH, TSH, and ACTH were negative in all adenomas.

By electron microscopy, the tumors of group I showed the characteristic features of somatotroph adenomas (see Table 2). In 7 cases the adenomas were densely granulated, in 4 adenomas the secretory granules were sparse, and in 1 case (12) the tumor was composed of both densely and sparsely granulated cells. Eleven tumors consisted of cells exhibiting the ultrastructural features of somatotrophs, whereas 1 tumor (case 1) was composed of mammosomatotrophs. In 1 case (8) in which the adenoma was interspersed with nerve cells, as seen by histology, the neural components were not recognized in the available electron microscopical specimens. In the case with acute infarction (case 9), the adenoma cells showed signs of advanced necrosis with nuclear pyknosis, clumping of chromatin, chromatolysis, multifocal distuption of the nuclear membrane, vesiculation of the endoplasmic reticulum, and marked dilation of the Golgi complex. The mitochondria were swollen and had lost 
Table 3. Pathological data (group II)

\begin{tabular}{ll}
\hline Case No. & $\begin{array}{l}\text { Light Microscopical } \\
\text { Findings }\end{array}$ \\
\hline 13 & $\begin{array}{l}\text { Strongly acidophilic ade- } \\
\text { noma with nuclear and } \\
\text { cellular pleomorphism } \\
\text { Immunopositivity: } \mathrm{GH}\end{array}$ \\
& $\begin{array}{l}\text { Fibrosis: no } \\
\text { Acidophilic adenoma, with } \\
\text { moderate pleomorphism } \\
\text { Immunopositivity: } \mathrm{GH}\end{array}$ \\
& Fibrosis: no
\end{tabular}

Acidophilic adenoma Immunopositivity: $\mathrm{GH}$ Fibrosis: no
Acidophilic adenoma Immunopositivity: GH Fibrosis: no

Chromophobic-acidophilic adenoma

Inmunopositivity: GH, PRL (occasional cells)

Fibrosis: slight, foca]

Cellular, partly acidophilic adenoma

Immunopositivity: $\mathrm{GH}$

Fibrosis: no

Very cellular, strongly acidophilic adenoma Immunopositivity: $\mathrm{GH}$ Fibrosis: slight, focal

\section{Electron Microscopical Findings}

Very densely granulated GH cell adenoma, with large secretory granules

Perivascular fibrosis: no

Densely granulated adenoma, with features (nuclear morphology, fibrous bodies) of sparsely granulated $\mathrm{GH}$ cell adenoma

Lysosomal accumulation: no

Densely granulated $\mathrm{GH}$ cell adenoma

Sparsely granulated GH cell adenoma consisting of small cells with fibrous bodies

Perivascular fibrosis: moderate

Sparsely granulated GH cell adenoma, with fibrous bodies

Lysosomal accumulation: no

Very densely granulated $\mathrm{GH}$ cell adenoma, consisting of very small cells with large secretory granules

Widening of perivascular space

Perivascular fibrosis: moderate

Partly densely, partly sparsely granulated $\mathrm{GH}$ cell adenoma with numerous fibrous bodies

Lysosomal accumulation: no Endocrine amyloid

Sparsely granulated GH cell adenoma, with minor densely granulated component

Endocrine amyloid

Very densely granulated $\mathrm{GH}$ cell adenoma, with large secretory granules

Lysosomal accumulation: strong

Widening of perivascular space

Endocrine amyloid

their internal compartments and, in some places, cell membranes were discontinuous. No cell damage was identified in the remaining 11 tumors. The nuclei and cell mem-

branes appeared to be normal. In 10 tumors, cell size and nuclear size did not seem to differ considerably from control cases, whereas in 2 cases $(3,12)$, cell and nuclear sizes appeared to be decreased. The nuclei had normal features. The endoplasmic reticulum membranes were conspicuous and wellpreserved. The Golgi complexes were prominent and consisted of sacculi and sacs containing immature secretory grantiles. The fibrous bodies, a characteristic feature of sparsely granulated $\mathrm{GH}$ cell adenomas [12] were noticeable without differing in size, number, and ultrastructural appearance from those seen in untreated somatotroph adenomas. The mitochondria were ovoid or rod-shaped and had tubular cristae and a moderately electron-dense matrix. The size and number of secretory granules seemed to be slightly larger and more numerous in 2 cases of densely granulated tumors $(3,4)$, whereas they were within the nomal range in the rest of the adenomas. As considerable variation existed from one tumor to the other and even between different areas of the same tumor, and because no morphometric analysis has been performed, definite conclusions could not be drawn as to whether the size and number of secretory granules had changed during treatment with octreotide. The lysosomes in 6 cases seemed to be unusually large and coalesced, containing lipid droplets and secretory granules. Crinophagy (i.e., the uptake of secretory granules into lysosomes) was more pronounced in the adenomas of patients treated with octreotide compared to those with no octreotide medication before surgery (Fig. 1). In 11 somatotroph adenomas, no exocytosis was observed, whereas in the mammosomatotroph adenoma, extrusion of secretory granules was common. The capillaries, in general, appeared to be normal and patent; no platelet aggregation, thrombosis, or vascular occlusions were seen. The endothelial cells showed no major alterations. In 3 cases, the perivascular space was wider than in the untreated cases; accumulation of fibroblasts and collagen fiber deposits were observed. This perivascular fibrosis was slight to moderate in 8 tumors and absent in 3 tumors. No interstitial fibrosis was found. It is noteworthy that 4 adenomas contained endocrine amyloid.

The morphological features by electron microscopy of the adenomas from group II 
Table 3. (continued)
22

24

4 Acidophilic adenoma Immunopositivity: $\mathrm{GH}$, FSH (occasional cells)

Fibrosis: mild, focal, perivascular
$\mathrm{GH}=$ growth hormone; $\mathrm{PRL}=$ prolactin; $\mathrm{FSH}=$ follicle-stimulating hormone.

(see Table 3) were not significantly different from those noted in group I. Six densely granulated adenomas were observed. In 5 adenomas, the secretory granules were sparse and, in 1 case (19), the tumor was composed of both densely and sparsely granulated cells. One densely granulated GH cell adenoma (case 14) consisted of cells that were often spherule-shaped and possessed eccentric, crescent-shaped nucleus and fibrous bodies (Fig. 2). These findings suggest that this tumor represented an originally sparsely granulated GH cell adenoma and accumulation of secretory granules was the result of

Figure 1. Mammosomatotroph adenoma of a patient (case 1/ treated with octreotide for 3 weeks. The adenoma cells contain large, irregular secretory granules, some of which have a mottled appearance (arrowhead). Note crinophagy (arrows). $(\times 10,500)$

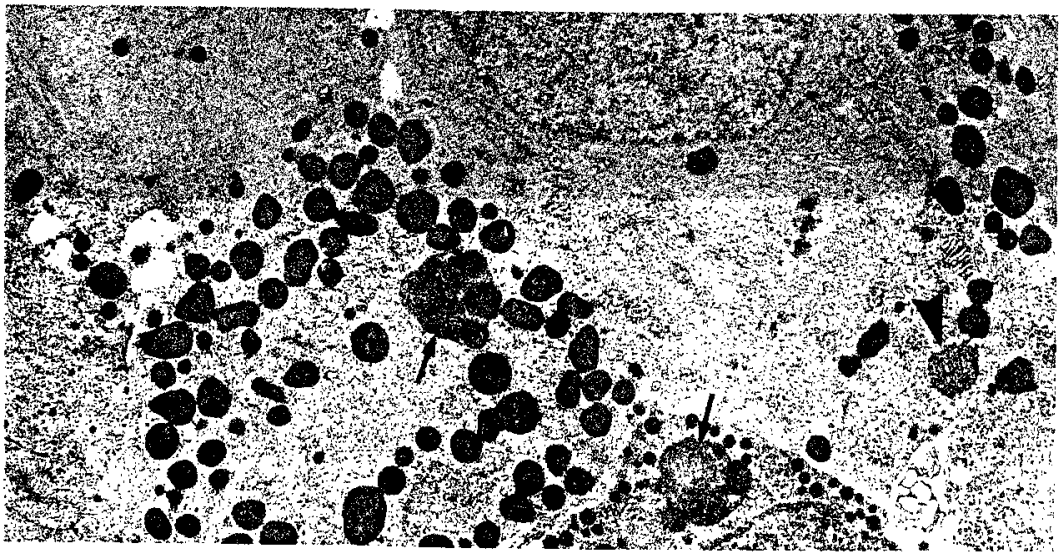

somatostatin analog treatment. Cell size seemed to be decreased in 2 cases $(16,18)$. In 3 of the densely granulated adenomas (cases $13,18,21)$, unusually numerous and large secretory granules were observed. Striking accumulation of lysosomes was noted in 1 case (21). Endocrine amyloid was present in 3 adenomas (Fig. 3).

\section{Discussion}

The suppressive activity of octreotide on $\mathrm{GH}$ secretion and its therapeutic value in the management of acromegaly are now well established $[7,8,14]$. This study was initiated to assess the effect of octreotide on volume, appearance, and morphological features of GH cell adenomas. Shrinkage of GH cell adenomas would make octreotide a useful drug to prepare patients for surgery [17]. In our series, involution was obtained in 11 of 19 cases, but it was only significant in 3 cases. Modest reduction in tumor size in 3 of 6 patients has been reported by Barnard and colleagues [4], whereas Ducasse and associates [9] described major regression in 1 patient treated with an infusion of octreotide. Barkan and co-workers [2] observed significant reduction of the tumor volume in 9 of 15 acromegalic patients.

The soft consistency of the adenomatous tissue found at surgery makes the operation easier. This softening effect of octreotide was recorded in 19 of our cases and was also observed by Spinas and colleagues [19] in 5 cases. However, larger series are required to reach definitive conclusions regarding the influence of octreotide on tissue softening, shrinkage of the adenoma, and potential benefits of these effects.

The morphological response of somatotroph adenomas to octreotide was not uniform and not marked, despite the fact that the drug caused clinical improvement and substantial decrease in serum GH levels in acromegalic patients. Lysosomes were large and numerous in several cells, and crinophagy was observed, suggesting that hormone release was suppressed and the retained secretory products of adenomatous cells were intracellularly degraded by lysosomes. Some adenomatous cells appeared to be smaller than those of untreated somatotroph adenomas and, in several tumors, varying degrees 


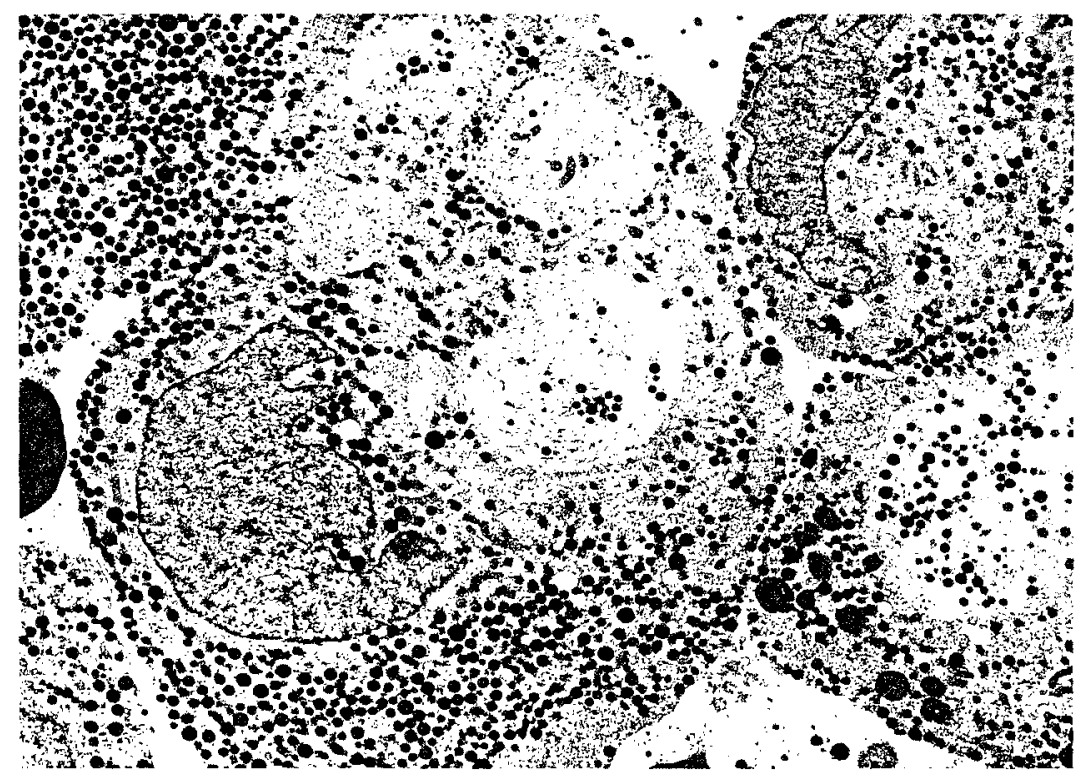

Figure 2. Growth hormone (GH) cell adenoma of a patient (case 14) treated with octreotide for 6 months. The adenoma cells are densely granulated. Dut otherwise they have ultrastructural characteristics of a sparsely granulated $\mathrm{GH}$ cell adenoma. $(\times 6,000)$ of perivascular fibrosis was noticeable. Some tumors removed from octreotide-treated paticnts were, however, morphologically indistinguishable from those not exposed to octreotide. Furthermore, no morphological difference could be evidenced between ade-
Figure 3. Foci of endocrine amyloid lasterisk) in the densely granulated growth hormone cell adenoma of a patient (case 21) treated with octreotide for 6 months. $(\times 11,800$.

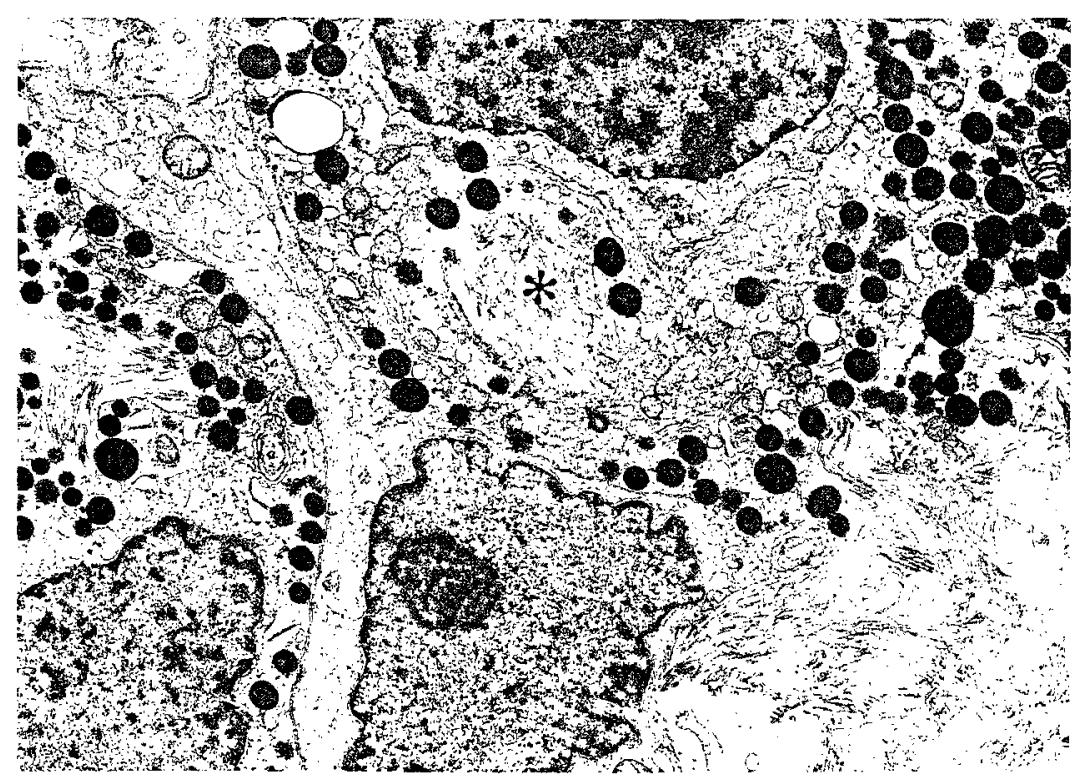

nomas treated for 3 weeks and those treated for 6 months. Also, no imporant difference could be detected between adenomas of patients presenting with an escape to the long-term treatment and those from patients who remained responsive. In the present series, with the exception of 2 adenomas with large areas of hemorrhagic necrosis, no cell necrosis, endothelial injury, platelet aggregation, vascular damage, or thrombosis was noted, indicating that octreotide had no direct cytotoxic or vasotoxic effects. The vascular change in the 2 exceptional cases was interpreted as an incidental finding, since hemorrhages and foci of necrosis also occur in tumors not exposed to octreotide [12].

Our morphological results are in agreement with the literature. Landolt and Osterwalder [16] found amyloid deposits and perivascular fibrosis but no consistent ultrastructural alterations in the secretory apparatus of adenoma cells. George and colleagues [10] investigated the somatotroph adenoma of a 36-ycar-old acromegalic woman treated for 10 days with octreotide. These authors noted an abundance of lysosomes with crinophagy and broadening of the perivascular space with slight fibrosis around the capillaries. Compared to 10 somatotroph adenomas not exposed to octreotide, the adenoma cells in the octreotide-treated patient appeared to be smaller and contained smaller nuclei as well as cytoplasm, and lysosomes occupied a larger area of the cytoplasmic volume. The nuclear-cytoplasmic ratio, cyroplasmic volume densities of endoplasmic reticulum, Golgi apparatus, mitochondria, and secretory granule diameters did not differ significantly from the control values. Barkan and co-workers [3] observed perivascular fibrosis and a reduction of both cytoplasmic and nuclear areas. These authors also reported 2 densely granulated adenomas with features of initially sparsely granulated adenomas, resembling the morphological appearance of 1 case in our series.

All these results are consistent with functional inhibition of $\mathrm{GH}$ release. Dopamine agonists, such as bromocriptine, cause reversible shrinkage of PRL-secreting pituitary adenomas associated with morphologically pronounced cell involution [21]. The changes are striking and are characterized by a substantial decrease in cell size and cytoplasmic and nuclear area, an increase in the 
nuclear-cytoplasmic ratio, and a reduction in cytoplasmic volume densities of endoplasmic reticulum membranes and Golgi apparatus. These changes are not apparent in GHsecreting pituitary adenomas exposed to octreotide. Thus, in tumors removed from octreotide-treated patients, a discrepancy exists between functional inhibition and morphological findings.

\section{References}

1. Asa SL, Scheithauer BW, Bilbao JM, Horvath E, Ryan N, Kovacs K, Randall RV, Laws ER, Singer W, Linfoot JA, Thorner MO, Vale W. A case for hypothalamic acromegaly: a clinical study of six patients with hypothalamic gangliocytomas producing growth hormone-releasing factor. J Clin Endocrinol Metab 58:796$803,1984$.

2. Barkan AL, Kelch RP, Hopwood NJ, Beitins IZ. Treatment of acromegaly with the longacting somatostatin analog SMS 201-995. J Clin Endocrinol Metab 66:16-23, 1988.

3. Barkan AL, Lloyd RV, Chandler WF, Hatfield MK, Gebarski SS, Kelch RP, Beitins IZ. Preoperative treatment of acromegaly with long-acting somatostatin analog SMS 201995: shrinkage of invasive pituitary macroadenomas and improved surgical remission rate. J Clin Endocrinol Metab 67:1040-1048, 1988.

4. Barnard LB, Grantham WG, Lamberton P, O'Dorisio TM, Jackson IM. Treatment of resistant acromegaly with long-acting somatostatin analogue (SMS 201-995). Ann Intern Med 105:856-861, 1986.

5. Bauer W, Briner U, Doepfner W, Haller R, Huguenin R, Marbach P, Petcher TJ, Press ]. SMS 201-995; a very potent and selective octapeptide analogue of somatostatin with prolonged action. Life Sci 31:1133-1140, 1983.

6. Besser GM, Mortimer CH, Carr D, Schally AV, Coy DH, Evered D, Kastin AJ, Turnbridge WMG, Thorner MO, Hall R. Growth hormone release inhibiting hormone in acromegaly. Br Med J 1:352-355, 1974.

7. Chiodini PG, Cozzi R, Dallabonzana D, Oppizzi G, Verde G, Petroncini M, Linzzi A, del Pozo E. Medical treatment of acromegaly with SMS 201-995, a somatostatin analog: a comparison with bromocriptine. J Clin Endocrinol Metab 64:447-453, 1987.

8. Comi R], Gorden P. The response of serum growth hormone levels to the long-acting somatostatin analog SMS 201-995 in acromegaly. ] Clin Endocrinol Metab 64:37-42, 1987.

9. Ducasse MCR, Tauber JP, Tourre A, Bonafe
A, Babin TH, Tauber MT, Harris AG, Bayard F. Shrinking of a growth hormone-producing pituitary tumor by continuous subcutaneous infusion of the somatostatin analog SMS 201-995. J Clin Endocrinol Metab 65:1042$1046,1987$.

10. George SR, Kovacs K, Asa SL, Horvath E, Cross EG, Burrow GN. Effect of SMS 201-995, a long acting somatostatin analogue, on the secretion and morphology of a pituitary growth hormone cell adenoma. Clin Endocrinol (Oxf) 26:395-405, 1987.

11. Guiot G, Oproiu A, Hertzog E, Fredy D. Adénomes hypophysaires. EMC Paris 17:340, 1969.

12. Kovacs $K$, Horvath $E$. Tumors of the pituitary gland. In: Atlas of tumor pathology, second series, fascicle 21. Washington, DC: Armed Forces Institute of Pathology, 1986, pp 1-269.

13. Lamberts $S W J$, Oosterom R, Neufeld $M$, del Pozo E. The somatostatin analog SMS 201995 induces long-acting inhibition of growth hormone secretion without rebound hypersecretion in acromegalic patients. I Clin Endocrinol Metab 60:1161-1165, 1985.

14. Lamberts SWJ, Uitterlinden P, Verschoor L, Van Dongen KJ, del Pozo E. Long-term treatment of acromegaly with the somatostatin analogue SMS 202-995. N Engl J Med 313:1576-1580, 1985.

15. Lamberts SWJ, Zweens $M$, Verschoor $L$, del Pozo E. A comparison among the growth hormone-lowering effects in acromegaly of the somatostatin analog SMS 201-995, bromocriptine and the combination of both drugs. J Clin Endocrinol Metab 63:16-19, 1986.

16. Landolt AM, Osterwalder V. Perivascular fibrosis in prolactinomas: is it increased by bromocriptine? J Clin Endocrinol Metab 58:1179-1183, 1984.

17. Landolt AM, Osterwalder V, Stuckmann G. Preoperative treatment of acromegaly with SMS 201-995: surgical and pathological observation. In: Ludecks DK, Tolis G, eds. Growth hormone, growth factors and acromegaly. New York: Raven Press, 1987, pp 229-244.

18. Scheithatier BW, Kovacs $K$, Randall RV, Horvath E, Okazaki H, Laws ER Jr. Hypothalamic neuronal hamartoma and adenohypophyseal neuronal choristoma: their association with growth hormone adenoma of the pituitary. J Neuropathol Exp Neurol 42:648-663, 1983.

19. Spinas GA, Zapf J, Landolt AM, Stuckmann G, Froesch ER. Preoperative treatment of 5 acromegalics with somatostatin analogue: endocrine and clinical observations. Acta Endocrinol (Copenh) 114:249-256, 1987.

20. Sternberger LA, Hardy PH, Cuculis J, Meyer 
HG. The unlabeled antibody enzyme method of immunochemistry. Preparation and properties of soluble antigen-antibody complex (horseradish peroxydase anti-horseradish peroxidase) and its use in the identification of spirochetes. J Histochem Cytochem 18:315333,1970

21. Tindall GT, Kovacs K, Horvath E, Thorner
MO. Human prolacin-producing adenomas and bromocriptine: a histological, immunocytochemical, ultrastructural, and morphometric study. J Clin Endocrinol Metab 55:1178$1183,1982$.

22. Vezina JL, Maltais R. La selle turcique dans l'acromégalie. Etude radiologique. Neurochirurgie 19(suppl 2):35, 1973 . 